Jan Pešina

jan.pesina@wp.pl

\title{
Výpravy do země jiných vad. Český (ne)romantizmus očima polských publicistů
}

ABSTRACT. Pešina Jan, Výpravy do země jiných vad. Český (ne)romantizmus očima polských publicistů (The expeditions to the land of other flaws. Czech (non)Romantism in the eyes of Polish publicists). „Poznańskie Studia Slawistyczne” 1. Poznań 2011. Rys Press, pp. 331-342. ISSN 2084-3011.

One of so called "proprietes of a national characte", which in Poland is sometimes stereotypically attributed to the Czechs, is a realistic or even pragmatic outlook on life, opposite to a Polish national romantic philosophy. This essay is devoted to the problem of the above mentioned romantism and realism as the way of thinking/mental state. On the base of Polish books published in the previous decade, dedicated to the modern Czech history, society and the wide understood culture, we have tried to answer the question, if and how Polish authors address the above mentioned stereotypical perception of the southern neighbour. It was displayed, that the most of the investigated authors, by choosing unique, romantic subjects and ideas, try to suppress the Polish stereotypical images of the Czechs.

Keywords: Czech, Romanticism, publicity, stereotype, national character.

V úvodu své nové knihy o Češích Zrób sobie raj cituje Mariusz Szczygieł výrok Oscara Wildea, že nejméně máme rádi lidi, kteří mají stejné vady jako my. Szczygieł má rád Čechy právě proto, že je to národ, který má úplně jiné vady než Poláci. Mezi těmito ,jinými vadami” významné místo zaujímají odlišné „národní povahové vlastnosti" Čechů a Poláků, jejichž zkoumání se v minulosti těšilo 
a dodnes těší pozornosti vědců, spisovatelů, politiků a v neposlední řadě také publicistů 1 .

Východiskem pro naše další uvažování bude stereotypní charakteristika tzv. české národní povahy označované jako neromantická (realistická, pragmatická), která stojí v opozici vůči polské (rovněž stereotypně viděné) romantické národní povaze. Předkládaný př́spěvek se nebude zabývat romantizmem jako uměleckým směrem, nýbrž v obecnějším smyslu jako životním postojem, jenž se vyznačuje iracionalitou, citovostí, snílkovstvím a nedostatečným smyslem pro skutečnost v konání i názorech ${ }^{2}$ a jenž bývá přisuzován Polákům, zatímco s Čechy jsou spojovány vlastnosti právě opačné - racionalita, životní realizmus či dokonce pragmatizmus a nedostatečný smysl pro velké ideály. S přihlédnutím $\mathrm{k}$ historickému kontextu doby vzniku romantizmu můžeme také mluvit o opozici polského romantizmu k českému biedermeieru, který se v 19. století vyhraňoval souběžně s romantizmem a v polemice s ním. Biedermeier, který „miloval uzavřené prostory, nevzrušivé děje a vyrovnané povahy"3, tu opět chápeme nejen jako umělecký proud,

1 S pokusy odpovědět na otázky po charakteru vlastního národa se můžeme v českém národním myšlení setkat již v raném novověku (B. Balbín). Na intenzitě pak získaly $\mathrm{v}$ období tzv. národního obrození (J. Kollár, K. Havlíček Borovský ad.). V druhé polovině 19. století se tato otázka stala také předmětem zájmu profesionálních sociologů, filozofi̊ a historiků (T. G. Masaryk, E. Chalupný). Nový podnět těmto snahám přinesla změněná geopolitická situace po vzniku samostatného Československa (F. Peroutka, E. Rádl). Po II. světové válce pak můžeme do dlouhé řady těch, kteří se zamýšleli nad českou národní povahou, zařadit většinu klíčových československých a českých politiků (V. Havel), filozofů (J. Patočka), historiků (J. Kroutvor), politologů (P. Pithart), literárních vědců (V. Černý), publicistů (J. Jedlička) atd. Srv. Z. Uherek, Ladislav Holý a zkoumání českého národního charakteru, in: L. Holý, Malý český člověk a skvělý český národ, Praha 2001, s. 187-188. Prakticky souběžně, i když samozřjmě v mnohem menším rozsahu, můžeme sledovat také polské pokusy o českou národní charakteristiku. Známé jsou např. výroky A. Mickiewicze, který ve svých pařižských přednáškách (1840-1844) mluvil o Češích jako o „hrstce filologů” nebo jako o ,slovanských Němcích”. Ne náhodou bývá také Mickiewiczův současník K. Havlíček Borovský, reprezentant odlišné (neromantické) národní filozofie, označován za Anti-Mickiewicze. Srv. Z. Tarajło-Lipowska, Męczennik czeskiej prawdy Karel Havliček Borovský, Wrocław 2002, s. 15 a 121. Na téma polské percepce českých národních vlastností v 19. stol. obsáhleji např. B. Jaroszewicz-Kleindienst, Czechy i Czesi w opiniach polskich pamiętnikarzy XIX wieku, Wrocław 1985.

2 W. Kopaliński, Słownik mitów i tradycji kultury, Warszawa 2003, s. 1103.

3 Srv. J. Lehár a kol., Česká literatura od počátků k dnešku, Praha 2004, s. 208. 
ale zejména jako životní postoj. Je třeba však zdůraznit, že napětí mezi romantickým a neromantickým uměleckým a životním postojem lze sledovat nejen na rozhraní dvou národních kultur, ale také uvnitř nich. $\mathrm{V}$ českém případě je známým př́ikladem odmítavé přijetí Máchova Máje v době jeho prvního vydání, kdy dobová kritika konstatovala, že dílo je sice umělecky hodnotné, ale z hlediska aktuálních úkolů českého národního hnutí nevhodné. Teprve o deset let později zazněly první hlasy obhajující K. H. Máchu a jeho dílo a pokolení vstupující do české literatury v padesátých letech 19. století „učinilo z Máje symbol vlastní odvahy"4.

Jako materiál pro předkládaný příspěvek posloužila vybraná polská knižní publicistika ${ }^{5}$ posledního desetiletí věnovaná moderním českým dějinám, české mentalitě, společnosti a široce chápané kultuře. Bude nás zajímat, jak se polští autoři vyrovnávají s výše zmíněným (tzn. neromantickým) stereotypním vnímáním jižního souseda. Zda a jak se pokoušejí o prolomení zažitých představ, jaké si o Češích často udržují Poláci, nebo zda tyto představy naopak pomáhají upevňovat.

Začněme chronologicky od knihy Antoniho Kroha O Szwejku i o nas, která je výsledkem mnohaletého švejkologického zájmu autora a která, i když byla připravena k vydání již na počátku 90. let minulého století, spatřila světlo světa až v roce 2002. Na první pohled by se mohlo zdát, že Krohova kniha je vyprávěním o švejkovských reáliích, které je určeno polským milovníkům slavného českého románu. Švejkovy osudy slouží však autorovi pouze jako východisko k širšímu vyprávění o dramatu I. světové války a soumraku c.k. monarchie, ale především o Češích, o jejich komplikované historii a utváření se jejich novodobé národní identity.

Román Osudy dobrého vojáka Švejka za světové války je pro Antoniho Kroha jednou z nejdemokratičtějších knih na světě, je dílem,

\footnotetext{
4 Srv. ibidem, s. 209-210.

5 S výjimkou knihy $O$ Szwejku i o nas byla většina textů obsažená v analyzovaných knihách již dříve publikována na stránkách polského tisku, z něhož je třeba na prvním místě jmenovat vlivný liberálně orientovaný deník „Gazeta Wyborcza”. Tato skutečnost byla pomocným kriteriem pro výběr textů, u nichž lze předpokládat, že se podílely na formování názorů širokého okruhu čtenářů na českou společnost, mentalitu, dějiny a kulturu.
} 
které poskytuje prostor pro mnoho způsobů čtení. Kniha může být podle Kroha chápána jako zábavná četba i jako filozofický traktát, sbírka anekdot i obraz své doby, komedie i tragédie. Tato demokratičnost knihy však v sobě skrývá i nebezpečí její mylné interpretace. Švejk jako populární figura bývá př́mo opakem románového Švejka. V českém prostředí se to projevuje nap̌r. používáním slov jako švejkovina nebo švejkováni $i^{6}$, která označují mentalitu značně odlišnou od mentality románového hrdiny. Dalším příkladem je obecně rozšířený pseudošvejkovský aforismus To chce klid, který bychom na stránkách románu Jaroslava Haška marně hledali`.

Mnohem dalekosáhlejší důsledky měla však mylná interpretace Švejka v Polsku. Román zde vešel v obecnou známost díky překladu Pawła Hulki-Laskowského na přelomu 20. a 30. let minulého století, kdy, jak konstatuje Antoni Kroh, česko-polské vztahy - politické, hospodárské i emocionální - byly na hony vzdáleny od „vzájemného porozumění a bratrské spolupráce" ${ }^{\circledR}$. Takový stav měl své historické kořeny v XIX. století. Vzájemná nedůvěra a nepochopení byly dále posíleny během I. světové války a těsně po ní v době československo-polských územních sporů. Chladné československo-polské vztahy nacházely svůj ohlas nejen v meziválečné polské publicistice, ale také $\mathrm{v}$ krásné literatuře. 20. léta jsou v polské literatuře (ostatně podobně jako v české) obdobím rozkvětu hrdinské legionářské literatury - vzpomínek, poezie, beletrie. Pokud se zde objeví Čech, zejména český voják, je to zpravidla postava negativní: zbabělec, pokrytec, člověk, který dbá výhradně o své zájmy, lhostejný ke cti a jiným vyšším citům, $v$ nejlepším př́ípadě směšný človíček, nic víc. V této atmosféře se polský čtenář seznámil se Švejkem. A protože negativní stereotypy vykazují značně delší životnost než podmínky, které je vytvořily, bývá Švejk dodnes v Polsku považován

6 Jak konstatují autoři syntézy Česká literatura od počátků $k$ dnešku: „Švejk a «švejkování» se však také stávaly ohniskem sporů o českou národní povahu. Byly považovány za příznačně český chytrácký pragmatismus, jemuž se nedostává vyšších etických hodnot, a podrobovány ostré kritice (katolík J. Durych, nacionalista V. Dyk, mluvčí mravního heroismu V. Černý, komunista J. Taufer)”. Srv. J. Lehár a kol., Česká literatura od počátkủ k dnešku, Praha 2004, s. 566.

A. Kroh, O Szwejku i o nas, Warszawa 2002, s. 7.

8 Ibidem, s. 7. 
za ztělesnění českého národního charakteru, symbol negativního stereotypu Čecha9.

Antoni Kroh s tímto obrazem ve své knize polemizuje. Důsledným návratem k románovému Švejkovi se snaží odlišit literární fikci od mylně konstruovaného „skutečného” obrazu českého národního charakteru. Takovou snahu je možné sledovat např. v kapitole věnované polozapomenutému hrdinovi československého odboje za první světové války generálu Jaroslavu Červinkovi. Krohův hrdina, který již ve věku osmi let složil slavnostní přísahu, že celý svůj život zasvětí obraně utiskovaného národa jako profesionální voják, je představen jako romantický hrdina, který je protikladem př́zemně pragmatického Švejka ${ }^{10}$.

S využitím napětí mezi romantickým a neromantickým uměleckým zobrazením skutečnosti je na pozadí Haškových Osudů dobrého vojáka Švejka za světové války (první sešitové vydání pochází z let 1921-1923) představena také Anabáze Rudolfa Medka (knižní pentalogie vycházející v letech 1921-1927). Dvě díla zcela rozdílně reflektující prožitek první světové války, dva paradoxně propletené životopisy jejich autorů. Oba vstoupili do literatury již před válkou, oba se pohybovali ve stejných kruzích umělecké bohémy, po celý život se neztráceli z dohledu a přesto si lze těžko představit dva rozdílnější charaktery. Po vypuknutí války Hašek i Medek narukovali do rakousko-uherské armády, z které záhy na východní frontě dezertovali na ruskou stranu, oba vstoupili do Československých legií, pak se jejich cesty rozešly: Medek se stal jednou z nejvýznamnějších osobností Československých legií, Hašek vstoupil do Rudé armády. Medek se do Prahy vrátil jako hrdina, byl povýšen do hodnosti plukovníka a v roce 1929 generála Československé armády, Hašek jako bývalý politický komisař Rudé armády vzbuzoval nedůvěru a podezření. Oba autoři také začali ve stejné době vydávat

9 Ibidem. Podle Martyny Lemańczyk jsou Krohovy názory příliš přísné a málo zohledňují dnešní percepci Švejka v Polsku. Současní Poláci mají podle Lemańczyk „k dobrému vojákovi srdečný, snad dokonce skrytě uznalý vztah”, o čemž svědčí například přítomnost jména Švejk v názvech četných polských restaurací, což jen stěží můžeme považovat za snahu o upevňování negativních stereotypů. Srv. M. Lemańczyk, Legendy a mýty české literatury v Polsku přelomu 20. a 21. století, in: S. Fedrová, A. Jedličková eds., Legendy a mýty české a slovenské literatury, Praha 2008, s. 183.

${ }_{10}$ A. Kroh, op. cit., s. 16-24. 
svá díla. Zatímco Medek se stal oficiálním státním spisovatelem, jehož legionářské romány, vzpomínky, poezie a divadelní hry byly vydávány ve velkých nákladech a autor za ně sklízel literární ceny, Hašek žijící v bídě vydával Švejka v sešitech vlastním nákladem ${ }^{11}$.

Dnes je postavení obou děl v obecném povědomí př́ímo opačné. Málokdo dnes v Česku, nemluvě již o zahraničí, zná Medkovu Anabázi oslavující hrdinný boj československých legionářů v Rusku. Medkovo dílo, které pomáhalo budovat ve 20. letech legionářskou legendu, přesně odpovídalo potřebám mladého státu. Haškův Švejk a zejména jeho budějovická anabáze (zvláště čteme-li ji v kontextu doby vzniku) tvoří jakýsi kontrapunkt Medkova díla. Jak konstatuje Antoni Kroh, je to mj. politický pamflet, bravurní publicistika na aktuální téma ${ }^{12}$. Haškův záměr se ve své době převážně nesetkal s pochopením ${ }^{13}$ a nesnadná interpretace díla je zdrojem nedorozumění dodnes.

V roce 2006 vyšly ve vydavatelství Czarne hned dvě knihy věnované Čechům: Gottland Mariusze Szczygła a Europa z płaskostopiem (Evropa s plochýma nohama) Aleksandra Kaczorowského. Szczygłova kniha získala v Polsku řadu prestižních ocenění a o rok později byla vydána rovněž v České republice, kde sklidila uznání nejen kritiků, ale i čtenářù, o čemž svědčí již pátý dotisk českého překladu. Čeští recenzenti shodně hodnotí Szczygłowu knihu jako svěží a nebanální pohled vnějšího pozorovatele, přičemž autor není pouhým zapisovatelem zaběhnutých mýtů, ale je také zaujatým reportérem, který př́mo v terénu vyhledává svědky událostí, konfrontuje jejich protikladné vzpomínky, pátrá $\mathrm{v}$ archivech a především se pozorně dívá kolem sebe. V př́ibězích obuvnického magnáta Tomáše Bati, herečky Lídy Baarové, tvůrců Stalinova pomníku v Praze, zpěvačky Marty Kubišové, spisovatele Jana Procházky a dalších se Szczygieł zároveň dotýká neuralgických bodů

11 Ibidem, s. 42-43.

12 Ibidem, s. 45.

13 V době vzniku Haškova Švejka se také ozvaly ojedinělé hlasy doceňující toto dílo. Podle Ivana Olbrachta se jednalo o „Lidské flegma zachycené z nové stránky. Český Honza poprvé objevený v umělé literatuře a postavený do rušného novodobého života”. Podle Maxe Broda ,je to postava, která se vynořila z nejtemnějších hlubin ducha lidu (...), vypovídá cosi nevypověditelného nejen o vlastním národě (...), má nadto co činit s nejtajemnějšími základy bytí všeho lidstva”, J. Lehár a kol., op. cit., s. 566. 
československých dějin XX. století, přičemž se snaží hrdiny svého vyprávění pochopit, aniž by je obhajoval nebo odsuzoval. Přitom však, jak konstatuje na stránkách časopisu Respekt Tereza Brdečková, „(Szczygłovi) jde v Gottlandu nakonec přesně o to, o čem zdánlivě nemluví. O morální princip ${ }^{14}$ '. Dodejme k tomu, že i když jde autorovi o morální princip, dokáže se ubránit moralizování. Dokáže se také, jak jen to je u vnějšího pozorovatele možné, oprostit od polské optiky filozofie dějin, která vyrůstá z jiné - romantické historické tradice.

Pokušení moralizovat a vynášet dějinné soudy zcela neodolal Aleksander Kaczorowski, autor další knihy, o které bude řeč. Europa z płaskostopiem je sbírkou rozhovorů s deseti osobnostmi českého kulturního a politického života. Jakési širší středoevropské doplnění pak tvoří pět dalších rozhovorů, např. s polským historikem Jerzym Tomaszewskim, slovinským spisovatelem Drago Jančarem nebo s mad'arským bohemistou Gyorgyem Vargou. Jak píše autor v úvodu své knihy, nerad používá termínu Středoevropan, což je podle něj výhodná myšlenková zkratka, která nám namlouvá, že Poláci, Češi a Mad’aři mají se sebou něco společného. Jistě mnoho společného mají, ale autora nejvíce přitahují rozdíly.

Za hlavní rozdíl mezi Čechy a Poláky považuje autor vztah těchto národů k vlastní historii, zatímco Poláky jejich dějiny tíží, Čechům nanejvýše překážejí. Úvod knihy je jakýmsi krátkým historickým přehledem rozdílných národních strategií nebo také konfrontací romantického (polského) a neromantického (českého) životního postoje: „My napínáme svaly, proléváme krev, slavíme zbytku světa neznámá výročí - a navrch mají i tak vždycky Češi. Je asi na čase zeptat se konečně, jak oni to dělají?"15. Podle Kaczorowského jsou Poláci připraveni spáchat hromadnou sebevraždu, jen aby se dobře zapsali do učebnic historie, zatímco Češi se v zájmu přežití raději přizpůsobí. Ve vztahu k okolnímu světu jsou Češi také na rozdíl od Poláků mistry vlastní propagace; podle autora dokázali Češi mnohem lépe než Poláci ,„prodat” světu svůj odboj za II. světové války - ve srovnání s Polskem nevelký rozsahem - a stejně tak i svoji roli

14 T. Brdečková, Příběhy ze Země Boží, http://respekt.ihned.cz/c1-36314020-pribehy-ze-zeme-bozi / poslední náhled: 9.01.2012.

15 A. Kaczorowski, Europa z płaskostopiem, Wołowiec 2006, s. 5. Citovaný úryvek v překladu autora článku. 
v demontáži komunizmu ve střední Evropě, a při tom lidí, kteří aktivně bojovali v Československu s komunismem, nebylo o mnoho více, než by bylo třeba k zaplnění pražské pivnice U Vejvodů ${ }^{16}$.

Dokonalým ztělesněním českých národních vad je pro Kaczorowského Švejk - vưči historii s velkým H je to sobec, váhavec a posměváček, který si zároveň umí poradit v každé situaci, při čemž nikdy neztrácí dobrou náladu a chut' do života a vždy dosáhne svého. Haškův Švejk je pro Kaczorovského ztělesněním většiny českého národa, zatímco Kafkův Josef K. ztělesňuje hrstku opozičníků, intelektuálů, spisovatelů, kteři často navzdory všemu, také navzdory svým krajanům, učinili český národ velkým. Těmto velkým Čechům (např. Petru Zelenkovi, Jiř́mu Menzelovi, Petru Pithartovi nebo Pavlu Kohoutovi) je věnována Kaczorovského kniha ${ }^{17}$.

Nezbývá než souhlasit s Václavem Burianem, který v recenzi Europy z plaskostopiem konstatuje, že Kaczorowského úvahy o českém národním charakteru jsou ,pro českého čtenáře četba místy př́jemná, místy trochu proti srsti. A občas si uvědomí, že i chytrý novinár pro efekt někdy pracuje se stereotypy"18. Některé z autorových závěrů (napřr. ten o Češích jako národě Švejků) má pravděpodobně svůj zdroj v hojně rozšířeném českém autostereotypu, jiné závěry (jako napřr. konstatování, že Češi dokáží sami sebe skvěle propagovat ve světě) mohou být pro českého čtenáře překvapivé. Za nejsilnější stránku knihy určené polským čtenářům lze považovat št’astný výběr oslovených osobností, jež díky svému rozmanitému profesnímu zaměření nabízejí pestrou mozaiku témat a názorů z oblasti nejen české, ale i středoevropské kultury a politiky.

V roce 2010 vydalo nakladatelství W. A. B. pod názvem Pepiki. Dramatyczne stulecie Czechów sbírku esejistických portrétů, většinou v Polsku málo známých postav českých dějin XX. století. O knize můžeme také mluvit jako o jakési alternativní učebnici českých moderních dějin, jejíž pomocí autor Mariusz Surosz polemizuje se zaběhnutými stereotypy.

Určité rozpaky vyvolává titul knížky - Pepíci, což je v Polsku všeobecně známé hanlivé pojmenování jižních sousedů. Těžko rozhodnout,

16 Ibidem, s. 5-8.

17 Ibidem, s. 9-12.

18 V. Burian, Co na nás ti Poláci vidí?, http://aktualne.centrum.cz/blogy-a-nazory/ clanek.phtml?id=339271 / poslední náhled: 9.01.2012. 
zda se jedná o záměrnou provokaci autora, nebo marketinkový tah vydavatelství. Předmluva, ve které autor doufá, že svojí knihou poněkud rozjasní doposud zamlžený obraz Čech, z kterého stále výsměšně pomrkává dobrý voják Švejk, napovídá spíše první možnosti ${ }^{19}$. Titul Pepíci však může zároveň vzbuzovat u Poláků také pozitivní emoce a navozovat představu lidí dobrých, otevřených a při tom pragmatických, což je odlišuje od Poláků náchylným k romantickým vzletům a autodestrukci.

Každé z portrétovaných osobností přiřkl autor jednoduchý přívlastek, někdy je to zaměstnání, původ nebo charakteristický prvek z jejího života. Žena a životní družka T. G. Masaryka - Charlotte Masaryková je prostě Američanka, vlastenec bojující za svobodné Československo - Milan Rastislav Štefánik je astronom, Milena Jesenská - novinářka, Klement Gottwald - truhlář, Karl Herman Frank - knihkupec. Na pozadí osudů hrdinů Suroszowy knihy poznává polský čtenář blíže české a československé dějiny XX. století. Seznamuje se s dramatickými životními osudy Mileny Jesenské, je svědkem tragického rozhodování a etických dilemat Aloise Eliáše a Emila Háchy. Vedle hrdinů nejnovějších českých a československých dějin představuje Suroszowa kniha také jejich antihrdiny. I o nich (K. Gottwald, K. H. Frank) autor píše věcně a objektivně se zrretelnou snahou pochopit motivy jejich činů vyrůstajících např. z pocitů sociální nebo národnostní frustrace.

Stereotypy a předsudky se vyznačují dlouhou životností. Nejlepší způsob, jak nad nimi zvítězit, je věcně o nich mluvit. Právě to dělá Mariusz Surosz. Bojuje se stereotypy a snaží se změnit obraz Čechů, který je doposud v Polsku monopolizován postavami próz Jaroslava Haška a Bohumila Hrabala, často mytizovanými a odtrženými od svého původního literárního zdroje. Pro změnu proto ukazuje národ vojáků, politiků, intelektuálů, umělců - hrdinů, nechybí však také antihrdinové.

Na závěr se vrat’me ke knize Mariusze Szczygła, o které byla řeč v úvodu. Knihu Zrób sobie raj vydalo v roce 2010 nakladatelství Czarne. Autor tak navázal na předcházející úspěšný titul Gottland další sbírkou literárních reportáží o Češích. Jak píše Szczygieł v úvodu knihy, snil o napsání knihy o své oblíbené zemi, aniž by měl ambice stvořit

19 M. Surosz, Pepiki. Dramatyczne stulecie Czechów, Warszawa 2010, s. 11-18. 
dílo, které poskytuje nějaký obraz, vynáší objektivní soudy, vytváří syntézu. Sám sebe považuje za nepořádného Čechofila, jehož knížka není kompetentním průvodcem po české kulture ani po Čechách, není objektivní, nedělá si na nic nárok. Je výhradně výsledkem autorových osobních fascinací, je to knížka o sympatii zástupce jedné země k jiné zemi. Čechy jsou pro Szczygła a další polské Čechofily, o kterých autor píše jako o jakémsi romantickém polotajném bratrstvu, jako sladký dezert, kterému se nedá odolat. Jsou pro Poláka tou částí jeho osobnosti, kterou nemá, po které se mu stýská, kterou hledá v Polsku a z mnoha důvodů ji nemůže nalézt ${ }^{20}$.

Zrób sobie raj je knihou o současných Češích a jejich zemi, spojuje v sobě deník, esej, fejeton a reportáž. Je to kniha přibližující polskému čtenáři významné a nezřídka také kontroverzní osobnosti současné české kultury, jako např. fotografa Jana Saudka, sochaře Davida Černého, filozofa Egona Bondyho, spisovatele Pavla Kohouta ad. Je to však také a možná především kniha o tak zvaných obyčejných lidech. Navzdory počátečním proklamacím o knize napsané jen tak pro radost, dotýká se autor řady důležitých otázek lidské existence, jako je hrdinství, vlastenectví nebo víra v Boha. Otázka, jak se žije bez Boha, vyjádřená někdy př́mo, jindy zas mezi rádky, se zdá být dokonce jakýmsi refrénem knihy.

Když se v roce 1920 Karel Čapek zamýšlel v Národnich listech nad významem a obsahem pojmu romantizmus, romantičnost, došel $\mathrm{k}$ nejednoznačným závěrům:

Romantická je idyla i orkán, jsou romantičtí zpátečníci i romantičtí revolucionáři; zdá se že romantičnost je schopna každé obměny. (...) Romantické je to, co je nevšední; a romantismus není $\mathrm{v}$ tomto nejobecnějším smyslu protivou $\mathrm{k}$ ničemu jinému než k stř́zlivosti. Člověku nábožensky střízlivému je náboženství romantismem; politickému rutinérovi je filozofická věda stejně romantismem jako kterýkoliv jiný druh poezie. Ve všech těchto prŕṕpadech je romantismus něco nepraktického, bezúčelného, zbytečného a přehnaného ${ }^{21}$.

20 M. Szczygieł, Zrób sobie raj, Wołowiec 2010, s. 7-11.

21 K. Čapek, Je véda romantická?, in: Karel Čapek, O uméní a kultuře II, http://ld.johanesville.net/capek-79-o-umeni-a-kulture-ii?page=38 / poslední náhled: 9.01.2012. 
Jednoznačnou odpověd' na otázku po obsahu a významu pojmu romantizmus jako vlastnosti českého národního charakteru nenajdeme ani ve sledované polské knižní publicistice poslední dekády. Napětí, které vzniká konfrontací romantického a neromantického (at' už zdánlivého nebo skutečného), můžeme ostatně pozorovat nejen na rozhraní obou národních kultur, ale také uvnitř nich. Jednotliví autoři zvolili na svých výpravách do české historie, kultury a společensko-politického dění různé způsoby narace vyplývající z jejich profesního zaměření - kulturního antropologa, novináře, historika. Za určitý leitmotiv Krohovy a Suroszovy knihy lze považovat polemiku se švejkovským (antihrdinským, neromantickým) mýtem českého národního charakteru. Kaczorowski svoji knihu rozhovorů s mimořádnými osobnostmi českého kulturního a společensko-politického života, které nazývá Josefy K., představil na pozadí podle svého názoru většinového českého společenství Josefů Švejků. V Szczygiełových knihách je spor mezi romantickým (polským) a neromantickým (českým) viděním, chápáním a prožíváním světa přitomen spíše latentně. Autor nicméně sám sebe několikrát označuje za př́ivržence českých (neromantických) životních postojů. I on však stejně jako ostatní autoři výběrem nevšedních, a tedy romantických, životních osudů, myšlenek a činů narušuje (více či méně vědomě) zaběhnutý stereotyp.

\section{Literatura}

Brdečková T., Př́iběhy ze Země Boži, http://respekt.ihned.cz/c1-36314020pribehy-ze-zeme-bozi / poslední náhled: 9.01.2012.

Burian V., Co na nás ti Poláci vidí? http://aktualne.centrum.cz/blogy-a-nazory/ clanek.phtml?id=339271 / poslední náhled: 9.01.2012.

Čapek K., Je věda romantická??, in: Karel Čapek, O uměni a kultuře II, http:// ld.johanesville.net/capek-79-o-umeni-a-kulture-ii?page=38 / poslední náhled: 9.01.2012.

Holý L., Malý český člověk a skvělý český národ. Národní identita a postkomunistická transformace společnosti, Praha 2001.

Kaczorowski A., Europa z płaskostopiem, Wołowiec 2006.

Kopaliński W., Stownik mitów i tradycji kultury, Warszawa 2003. 
Kroh A., O Szwejku i o nas, Warszawa 2002.

Lehár J. a kol., Česká literatura od počátků k dnešku, Praha 2004.

Lemańczyk M., Legendy a mýty české literatury v Polsku prélomu 20. a 21. století, in: S. Fedrová, A. Jedličková eds., Legendy a mýty české a slovenské literatury, Praha 2008, s. 182-192.

Surosz M., Pepiki. Dramatyczne stulecie Czechów, Warszawa 2010.

Szczygieł M., Gottland, Wołowiec 2006.

Szczygieł M., Zrób sobie raj, Wołowiec 2010 .

Tarajło-Lipowska Z., Męczennik czeskiej prawdy Karel Havlíček Borovský, Wrocław 2002. 